\title{
Dietary lipoic acid-dependent changes in the activity and mRNA levels of hepatic lipogenic enzymes in rats
}

\author{
Doan Thi Thanh Huong $\dagger$ and Takashi Ide* \\ Laboratory of Nutritional Function, Division of Food Function, National Food Research Institute, 2-1-12 Kannondai, \\ Tsukuba 305-8642, Japan \\ (Received 27 May 2007 - Revised 28 September 2007 - Accepted 31 October 2007 - First published online 7 December 2007)
}

Effects of dietary $\alpha$-lipoic acid on hepatic and serum lipid concentrations and the activity and mRNA levels of lipogenic enzymes were examined in rats. Rats were fed experimental diets containing varying amounts of lipoic acid $(0,1,2.5,5 \mathrm{~g} / \mathrm{kg})$ for $21 \mathrm{~d}$. Lipoic acid profoundly decreased serum and liver concentrations of TAG, and also lowered serum concentrations of phospholipid and NEFA, and the concentration of cholesterol in the liver. A hypoglycaemic effect of this compound was also observed. Lipoic acid dose-dependently decreased the activity and mRNA levels of fatty acid synthase, ATP-citrate lyase, glucose 6-phosphate dehydrogenase, malic enzyme and pyruvate kinase in the liver despite that reductions were considerably attenuated in the NADPH-producing enzymes. This compound also dose-dependently lowered the mRNA levels of spot 14, adiponutrin, stearoyl-CoA desaturase 1 , and $\Delta^{5}$ - and $\Delta^{6}$-desaturases. In addition, lipoic acid dose-dependently lowered serum concentrations of insulin and leptin, but increased those of adiponectin. Lipoic acid appeared to reduce hepatic lipogenesis and hence decreases serum and liver lipid levels. Alterations in serum concentrations of insulin and (or) adiponectin may trigger this consequence.

Lipoic acid: Hepatic fatty acid synthesis: Insulin: Leptin: Adiponectin

$\alpha$-Lipoic acid is a natural compound widely distributed in plants and animals, and is synthesized through a reaction catalysed by lipoic acid synthase within the mitochondria ${ }^{(1)}$. Lipoic acid functions as a cofactor within mitochondrial pyruvate dehydrogenase and $\alpha$-ketoglutarate dehydrogenase ${ }^{(1,2)}$. Aside from its role in the mitochondrial metabolic pathway, lipoic acid when supplemented in diets exerts various physiological activities in experimental animals. Lipoic acid is enzymatically reduced to form dihydrolipoic acid in the cytosol and mitochodria ${ }^{(1)}$. Lipoic acid and dihydrolipoic acid are powerful antioxidants. Therefore, dietary lipoic acid is effective in attenuating oxidative stress induced by drugs ${ }^{(3)}$, a high-fructose $\operatorname{diet}^{(4)}$, ageing ${ }^{(5)}$ and physical exercise ${ }^{(6)}$. Also, lipoic acid modulates glucose metabolism and is effective in ameliorating insulin resistance and type 2 diabetes ${ }^{(7)}$.

In addition, a hypolipidaemic effect of lipoic acid has been reported by many investigators. Yi \& Maeda ${ }^{(8)}$ reported that a diet containing $1.65 \mathrm{~g}$ lipoic acid $/ \mathrm{kg}$ reduced plasma cholesterol concentrations in streptozotocin-induced diabetic apoEdeficient mice. Thirunavukkarasu \& Anuradha $^{(4)}$ reported that the intraperitoneal injection of lipoic acid (35 and $70 \mathrm{mg} / \mathrm{kg}$ body weight per d) reduced plasma cholesterol, TAG, phospholipid and NEFA levels in fructose-fed rats. Also, it has been reported that the administration of lipoic acid ( $35 \mathrm{mg} / \mathrm{kg}$ body weight per d) intraperitoneally once a week prevented adriamycin-induced hyperlipidaemia in rats ${ }^{(9)}$. Ford et al. ${ }^{(10)}$ observed that dietary supplementation of lipoic acid to give a dose of approximately $300 \mathrm{mg} / \mathrm{kg}$ body weight per $\mathrm{d}$, reduced serum TAG concentrations in rats with streptozotocin-induced diabetes. Song et al. ${ }^{(11)}$ reported that a diet containing $5 \mathrm{~g}$ lipoic acid/ $\mathrm{kg}$ significantly decreased serum concentrations of TAG and NEFA, and TAG concentrations in pancreatic islets and soleus muscles in an animal model of obesity and diabetes mellitus (Otsuka Long-Evans Tokushima Fatty (OLETF) rats). However, the mechanism underlying the hypolipidaemic effect of $\alpha$-lipoic acid is poorly understood. In this context, Lee et al. ${ }^{(12)}$ recently reported that a diet containing $10 \mathrm{~g}$ lipoic acid $/ \mathrm{kg}$ reduced mRNA levels of fatty acid synthase and sterol regulatory element binding protein (SREBP)-1, a transcription factor that regulates the gene expression of lipogenic enzyme ${ }^{(13)}$, in acyl-CoA synthase transgenic mice after $4 \mathrm{~d}$ and 6 weeks of feeding. However, it is still difficult to conclude that lipoic acid has a specific physiological role in reducing lipogenesis, because it considerably reduced food intake in their study. Also, there is the possibility that the reduction by dietary lipoic acid of the mRNA expression of fatty acid synthase is a particular phenomenon observable only in acyl-CoA synthase transgenic mice. Moreover, it should be stated that alterations in the mRNA level may not necessarily accompany parallel changes in the amount of enzyme protein and hence its activity. In this context, we examined the effect of diets

Abbreviations: AMPK, AMP-activated protein kinase; OLETF rats, Otsuka Long-Evans Tokushima Fatty rats; SREBP, sterol regulatory element binding protein.

* Corresponding author: Dr Takashi Ide, fax + 8129838 7996, email idetaka@affrc.go.jp

$\dagger$ Present address: Institute of Biotechnology, Vietnamese Academy of Science and Technology, 18 Hoang Quoc Viet, Cau Giay, Hanoi, Vietnam 
containing varying amounts of $\alpha$-lipoic acid on the activity and mRNA levels of hepatic enzymes involved in lipogenesis in Sprague-Dawley rats in the present study.

\section{Materials and methods}

\section{Animals and diets}

Male Sprague-Dawley rats obtained from Charles River Japan (Kanagawa, Japan), were housed individually in animal cages in a room with controlled temperature $\left(20-22^{\circ} \mathrm{C}\right)$, humidity (55-65\%) and lighting (lights on from 07.00 to 19.00 hours), and fed a commercial non-purified diet (Type NMF, Oriental Yeast Co., Tokyo, Japan). After $7 \mathrm{~d}$ of acclimatization, rats were fed purified experimental diets containing $0,1,2.5$ and $5 \mathrm{~g}$ lipoic acid/kg for $21 \mathrm{~d}$. The basal composition of the experimental diet was (g/kg): palm oil, 100; casein, 200; maize starch, 150; cellulose, 20; mineral mixture ${ }^{(14)}, 35$; vitamin mixture ${ }^{(14)}, 1 \cdot 0$; L-cystine, 3; choline bitartrate, 2.5 and saccharose to $1 \mathrm{~kg}$. Chemically synthesized DL- $\alpha$-lipoic acid with a purity exceeding $990 \mathrm{~g} /$ $\mathrm{kg}$ (maker's statement) was purchased from Tokyo Chemical Industry (Tokyo, Japan). Varying amounts of lipoic acid were added to the diet in lieu of saccharose. Previous animal experiments $^{(10-12,15-17)}$ using rats or mice employed dietary levels of lipoic acid of $0.5-10 \mathrm{~g} / \mathrm{kg}$, which are similar to the levels employed in the present study. Many previous human studies employed a dose of lipoic acid of $600-2400 \mathrm{mg} / \mathrm{d}$ per person ${ }^{(18,19)}$. A nutritional survey conducted in Japan in 2005 (http://www.mhlw.go.jp/houdou/2006/05/h0508-1.html) indicated the average food intake of adults to be $423 \mathrm{~g} / \mathrm{d}$. A similar value $(403 \mathrm{~g} / \mathrm{d})$ was reported in a nutritional survey conducted in the UK in 2001 (http://www.statistics.gov.uk/downloads/ theme_health/NDNS_V2.pdf). Therefore, the intake of diets containing $1,2.5$ and $5 \mathrm{~g}$ lipoic acid/ $\mathrm{kg}$ employed in the present animal study correspond to the daily consumption of approximately 400, 1000 and $2000 \mathrm{mg} /$ person of this compound when extrapolated in man. These values are comparable to those employed in previous human studies. The present study was approved by the review board of animal ethics of our institute and we followed the institute's guidelines in the care and use of laboratory animals.

\section{Enzyme assays}

Upon termination of the experimental period, animals were anaesthetized using diethyl ether and killed by bleeding from the abdominal aorta, after which livers were excised immediately. About $1.5 \mathrm{~g}$ of each liver was homogenized with $10 \mathrm{ml} \quad 0.25 \mathrm{M}$-sucrose containing $1 \mathrm{~mm}$-EDTA and $3 \mathrm{~mm}-$ Tris- $\mathrm{HCl}(\mathrm{pH} \mathrm{7.2)}$ and the homogenate was centrifuged at $200000 \mathrm{~g}$ for $30 \mathrm{~min}$. The activities of enzymes involved in fatty acid synthesis were measured spectrophotometrically using the $200000 \mathrm{~g}$ supernatant of the liver homogenate. Fatty acid synthase activity was measured as malonyl-CoA-dependent oxidation of NADPH in the presence of acetyl-CoA ${ }^{(20)}$. ATP-citrate lyase activity represented the rate of CoA-dependent oxidation of $\mathrm{NADH}$ in the presence of citrate, ATP and malate dehydrogenase (Oriental Yeast Co.) ${ }^{(21)}$. The rate of NADP reduction following the addition of malic acid was analysed to measure malic enzyme activity ${ }^{(22)}$. The rate of glucose 6-phosphate-dependent reduction of NADP in the presence of excess amounts of 6-phosphogluconate dehydrogenase (Oriental Yeast Co.) represented glucose 6-phosphate dehydrogenase activity ${ }^{(23)}$. Pyruvate kinase activity was measured as the rate of phosphoenolpyruvate-dependent oxidation of NADH in the presence of ADP and lactate dehydrogenase (Roche Diagnostics, Manheim, Germany) ${ }^{(24)}$.

\section{RNA analysis}

Hepatic RNA was extracted using the acid guanidium thiocyanate-phenol-chloroform method ${ }^{(25)}$ and mRNA abundance was analysed by a quantitative real-time PCR using an Applied Biosystems Prism 7000 sequence detection system (Applied Biosystems, Foster City, CA, USA). Total RNA was reverse-transcribed with random hexamers using MultiScribe reverse transcriptase (Applied Biosystems) to generate cDNA. The PCR mixture in a final volume of $20 \mu$ l contained $20 \mathrm{ng}$ cDNA, $900 \mathrm{~nm}$ each of the forward and reverse primers, $250 \mathrm{~nm}$ TaqMan probe and $10 \mu \mathrm{l} \times 2$ PCR master mix (Applied Biosystems). mRNA abundance was calculated as a ratio to the mRNA abundance of $\beta$-actin in each cDNA sample and expressed as a percentage, assigning a value of 100 for rats fed a control diet free of lipoic acid. Nucleotide sequences of forward and reverse primers and probes to detect the respective mRNA were the same as described previously $^{(26)}$.

Analyses of serum and liver lipids, and serum glucose, leptin, adiponectin and insulin

Liver lipids were extracted and purified ${ }^{(27)}$. Amounts of $\mathrm{TAG}^{(28)}$ and phospholipid ${ }^{(29)}$ in the liver lipid extracts were analysed colorimetrically and the amount of cholesterol was measured enzymatically ${ }^{(30)}$. Serum TAG, cholesterol, phospholipid and NEFA concentrations were measured using commercial enzyme kits (Wako Pure Chemical, Osaka, Japan). Serum leptin (Morinaga Co., Tokyo, Japan), adiponectin (Otsuka Pharmaceutical Co., Tokushima, Japan) and insulin (Morinaga Co.) concentrations were analysed with commercial ELISA kits.

\section{Statistical analysis}

Data are expressed as means and their standard errors. StatView for Macintosh (SAS Institute Inc., Cary, NC, USA) was used for the statistical analysis. The data were subjected to a one-way ANOVA, followed by a Tukey-Kramer posthoc analysis to detect significant differences of the means at the level of $P<0.05$.

\section{Results}

Serum and liver lipid concentrations and serum concentrations of glucose, insulin and adipokines

Lipoic acid at a dietary level of up to $2.5 \mathrm{~g} / \mathrm{kg}$ did not affect the food intake (20.5 (SEM 0.7), 18.9 (SEM 0.8) and 19.4 (SEM 0.8) $\mathrm{g} / \mathrm{d}$ for rats fed diets containing 0,1 and $2.5 \mathrm{~g} / \mathrm{kg}$ lipoic acid, respectively) or growth (169 (SEM 8), 157 (SEM 9) and 149 (SEM 9) g/21d, respectively) of the animals. However, a diet containing $5 \mathrm{~g}$ lipoic acid/ $\mathrm{kg}$ compared to a 
diet free of this compound significantly $(P<0 \cdot 01)$ reduced these parameters (13.6 (SEM 0.4) g/d and 84.1 (SEM 5.4) g/21 d, respectively). Liver weights were the same among rats fed diets containing 0,1 and $2.5 \mathrm{~g}$ lipoic acid/ $\mathrm{kg}$ (4.92 (SEM 0.14 ), 5.08 (SEM 0.14) and 5.26 (SEM 0.11) g/100 g body weight, respectively). However, this parameter was significantly higher in rats fed a $5 \mathrm{~g}$ lipoic acid/ $\mathrm{kg}$ diet $(5.61$ (SEM $0.12) \mathrm{g} / 100 \mathrm{~g}$ body weight) than in the animals fed a lipoic acid-free diet. Epididymal and perirenal adipose tissue weights were significantly lower in rats fed a diet containing $5 \mathrm{~g}$ lipoic acid/kg (0.97 (SEM 0.08) and 0.92 (SEM 0.12) g/100 g body weight, respectively) than in the animals fed a lipoic acid-free diet (1.51 (SEM 0.19) and 1.62 (SEM 0.25) g/100 g body weight, respectively). However, these values in rats fed 1 (1.38 (SEM 0.08) and 1.61 (SEM 0.13) g/100 g body weight, for epididymal and perirenal depots, respectively) and 2.5 (1.61 (SEM 0.15) g/100 g body weight, respectively) g lipoic acid/kg were the same as those in the animals fed a lipoic acid-free diet.

A diet containing $1 \mathrm{~g}$ lipoic acid/ $\mathrm{kg}$ reduced the serum TAG concentration to a level one-half that observed with a diet free of this compound (Table 1). The value obtained with a diet containing $2.5 \mathrm{~g}$ lipoic acid/ $\mathrm{kg}$ was indistinguishable from the level observed with a diet containing $1 \mathrm{~g}$ lipoic acid $/ \mathrm{kg}$, but a diet containing $5 \mathrm{~g} / \mathrm{kg}$ of this compound further decreased this parameter to one-third that observed with a lipoic acid-free diet. Diets containing varying amounts of lipoic acid compared to a lipoic acid-free diet also significantly reduced serum concentrations of phospholipid and NEFA. However, lipoic acid was rather ineffective in reducing serum concentrations of cholesterol. A diet containing $5 \mathrm{~g}$ lipoic acid $/ \mathrm{kg}$ relative to a diet free of this compound caused a significant $26 \%$ decrease in this parameter, but the values obtained with diets containing 1 and $2.5 \mathrm{~g}$ lipoic $\mathrm{acid} / \mathrm{kg}$ were the same as those observed with a lipoic acidfree diet. Lipoic acid dose-dependently decreased serum concentrations of glucose. The values observed with diets containing $1,2.5$ and $5 \mathrm{~g}$ lipoic acid $/ \mathrm{kg}$ were 11,20 and $30 \%$ lower, respectively, than the level observed with a lipoic acid-free diet. Dietary lipoic acid greatly decreased serum concentrations of insulin. The diets containing 1 and $2.5 \mathrm{~g}$ lipoic acid/ $\mathrm{kg}$ caused 44 and $57 \%$ decreases, respectively, in this parameter. The level observed with a diet containing $5 \mathrm{~g}$ lipoic acid $/ \mathrm{kg}$ was very low (94\% decrease). Lipoic acid also affected serum concentrations of adipokines that modify lipid, energy and glucose metabolism. This compound dosedependently decreased serum concentrations of leptin. The values observed with $1,2.5$ and $5 \mathrm{~g}$ lipoic acid/ $\mathrm{kg}$ were 43 , 53 and $66 \%$ lower than the level obtained with a lipoic acid-free diet. In contrast, lipoic acid increased serum concentrations of adiponectin. A diet containing $1 \mathrm{~g}$ lipoic acid $/ \mathrm{kg}$ relative to a diet free of this compound caused a $75 \%$ increase in this parameter, and the level was doubled with a diet containing $2.5 \mathrm{~g}$ lipoic acid $/ \mathrm{kg}$. However, the levels obtained with diets containing 2.5 and $5 \mathrm{~g}$ lipoic acid/ $\mathrm{kg}$ were indistinguishable. A significant positive correlation was observed between the serum concentrations of insulin and leptin ( $r$ 0.759, $P<0.001)$. In contrast, a significant negative correlation was observed between the serum concentrations of insulin and adiponectin ( $r$ 0.508, $P=0.005)$.

Lipoic acid greatly and dose-dependently decreased hepatic concentrations of TAG. Diets containing 1, 2.5 and $5 \mathrm{~g}$ lipoic acid/kg compared to a diet free of this compound caused 58 , 75 and $82 \%$ decreases, respectively, in this parameter. Although the extent of the reduction was attenuated, lipoic acid also dose-dependently decreased hepatic concentrations of cholesterol $(20,29$ and $37 \%$ decreases for rats fed diets containing $1,2.5$ and $5 \mathrm{~g}$ lipoic acid $/ \mathrm{kg}$, respectively). However, diets containing varying amounts of lipoic acid slightly but significantly increased hepatic concentrations of phospholipid $(8,15$ and $15 \%$ increases for rats fed diets containing 1 , 2.5 and $5 \mathrm{~g}$ lipoic acid/kg, respectively).

\section{Activity of enzymes involved in hepatic fatty acid synthesis}

Dietary lipoic acid dose-dependently decreased the activity of lipogenic enzymes and pyruvate kinase (Fig. 1). Diets containing $1,2.5$ and $5 \mathrm{~g}$ lipoic acid/kg caused 35, 66 and $86 \%$

Table 1. Effect of dietary lipoic acid on serum and liver lipid concentrations, and serum concentrations of glucose, insulin and adipocytokines

(Mean values with their standard errors, $n 7-8$ )

\begin{tabular}{|c|c|c|c|c|c|c|c|c|}
\hline & \multicolumn{8}{|c|}{ Dietary lipoic acid (g/kg) } \\
\hline & \multicolumn{2}{|c|}{0} & \multicolumn{2}{|c|}{1} & \multicolumn{2}{|c|}{2.5} & \multicolumn{2}{|c|}{5} \\
\hline & Mean & SEM & Mean & SEM & Mean & SEM & Mean & SEM \\
\hline \multicolumn{9}{|l|}{ Serum components } \\
\hline TAG $(\mathrm{mmol} / \mathrm{l})$ & 3.49 & 0.47 & $1.56^{\star \star}$ & 0.17 & $1 \cdot 69^{\star *}$ & 0.06 & $1 \cdot 10^{\star \star}$ & 0.14 \\
\hline Cholesterol $(\mathrm{mmol} / \mathrm{l})$ & $2 \cdot 75$ & 0.19 & $2 \cdot 61$ & 0.13 & 2.50 & 0.08 & $2 \cdot 04^{\star \star}$ & 0.06 \\
\hline Phospholipid (mmol/l) & 3.48 & 0.17 & $2 \cdot 76^{\star \star}$ & 0.13 & $2 \cdot 71^{\star *}$ & 0.10 & $2 \cdot 07^{\star \star}$ & 0.06 \\
\hline $\operatorname{NEFA}(\mathrm{mmol} / \mathrm{l})$ & $1 \cdot 13$ & 0.06 & $0.782^{\star *}$ & 0.043 & $0.762^{\star \star}$ & 0.067 & $0.621^{\star *}$ & 0.037 \\
\hline Glucose (mmol/l) & $8 \cdot 61$ & 0.34 & $7 \cdot 69^{\star \star}$ & $0 \cdot 15$ & $6 \cdot 88^{\star \star}$ & 0.23 & $6 \cdot 03^{\star \star}$ & 0.18 \\
\hline Insulin $(\mu \mathrm{g} / \mathrm{l})$ & $6 \cdot 61$ & 0.91 & $3 \cdot 72^{\star \star}$ & 0.69 & $2 \cdot 82^{\star *}$ & 0.85 & $0.371^{\star *}$ & 0.036 \\
\hline Leptin $(\mu \mathrm{g} / \mathrm{l})$ & $9 \cdot 61$ & 1.01 & $5 \cdot 44^{\star \star}$ & 0.45 & $4 \cdot 48^{\star \star}$ & 0.56 & $3 \cdot 25^{\star \star}$ & 0.15 \\
\hline Adiponectin (mg/l) & $3 \cdot 70$ & 0.37 & $6 \cdot 43^{\star *}$ & 0.30 & $7 \cdot 59^{\star *}$ & 0.48 & $7 \cdot 44^{\star *}$ & 0.91 \\
\hline \multicolumn{9}{|l|}{ Liver lipids $(\mu \mathrm{mol} / \mathrm{g})$} \\
\hline TAG & $48 \cdot 6$ & $5 \cdot 6$ & $20 \cdot 4^{\star \star}$ & $1 \cdot 7$ & $12 \cdot 0^{\star \star}$ & $1 \cdot 3$ & $8 \cdot 62^{\star *}$ & $1 \cdot 32$ \\
\hline Cholesterol & $7 \cdot 13$ & 0.36 & $5 \cdot 71^{\star \star}$ & 0.18 & $5 \cdot 06^{\star \star}$ & 0.09 & $4 \cdot 52^{\star \star}$ & 0.10 \\
\hline Phospholipid & 35.9 & 1.0 & $38 \cdot 7^{\star}$ & 0.6 & $41 \cdot 4^{\star \star}$ & $1 \cdot 1$ & $41.9^{\star \star}$ & 1.0 \\
\hline
\end{tabular}

Mean values were significantly different from those of rats fed a lipoic acid-free diet: ${ }^{\star} P<0.05,{ }^{\star \star} P<0.01$. 

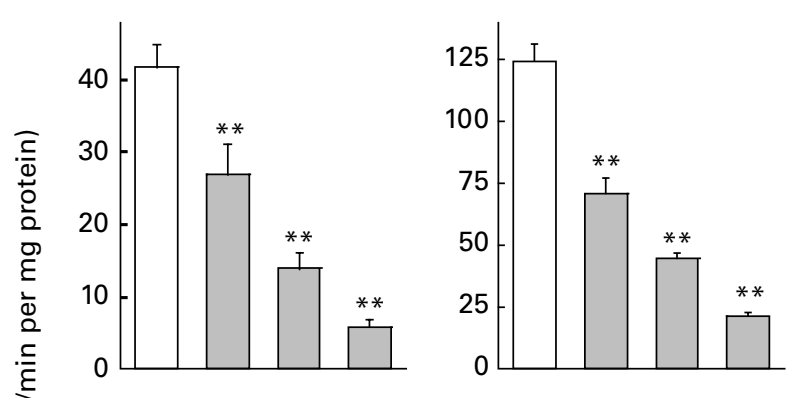

Glucose 6-phosphate dehydrogenase

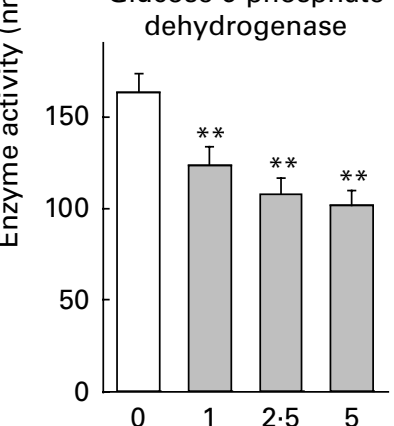

Malic enzyme

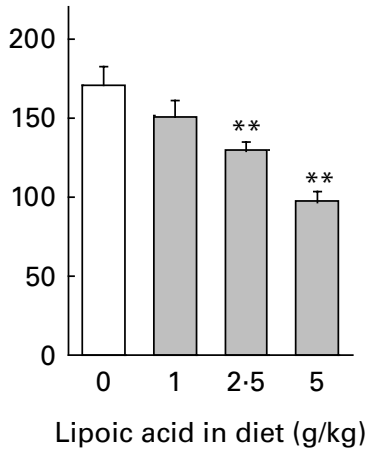

Pyruvate kinase

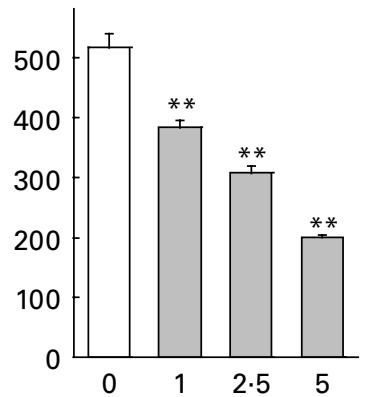

vertical bars $(n 7-8)$. Mean values were significantly different from those of rats fed a lipoic acid-free diet: ${ }^{*} P<0.05,{ }^{*} P<0.01$.

decreases in the activity of fatty acid synthase, respectively. The magnitude of the changes was similar for the activity of ATPcitrate lyase $(43,64$ and $83 \%$ decreases for rats fed diets containing 1, 2.5 and $5 \mathrm{~g}$ lipoic acid/kg, respectively). Lipoic acid-dependent decreases were considerably attenuated for the activities of enzymes needed to generate NADPH in the cytosol (glucose 6-phosphate dehydrogenase and malic enzyme). A diet containing $1 \mathrm{~g}$ lipoic acid/ $\mathrm{kg}$ caused 24 and $11 \%$ decreases in the activity of glucose 6-phosphate dehydrogenase and malic enzyme, respectively, and the reduction was not significant in the latter case. Diets containing 2.5 and $5 \mathrm{~g}$ lipoic acid/ $/ \mathrm{kg}$ caused 34 and $38 \%$, and 24 and $43 \%$ decreases in the activity of glucose 6-phosphate dehydrogenase and malic enzyme, respectively. Pyruvate kinase, an enzyme involved in the glycolytic pathway in the liver, is co-ordinately regulated with other enzymes involved in lipogenesis, and is considered to participate in the regulation of fatty acid synthesis ${ }^{(31)}$. Dietary lipoic acid also dose-dependently decreased the activity of this enzyme (26, 40 and $61 \%$ decreases in rats fed diets containing $1,2.5$ and $5 \mathrm{~g}$ lipoic acid/kg, respectively).

mRNA levels of hepatic proteins involved in lipogenesis and fatty acid desaturation

mRNA abundance was calculated as a ratio to the mRNA abundance of $\beta$-actin and expressed as a percentage, assigning a value of 100 for rats fed a control diet free of lipoic acid (Fig. 2). Mammals have four types of pyruvate kinase named $\mathrm{L}, \mathrm{M} 1, \mathrm{M} 2$ and $\mathrm{R}^{(32)}$. Type $\mathrm{L}$ is the major isozyme in the liver. Lipoic acid at a dietary level as low as $1 \mathrm{~g} / \mathrm{kg}$ caused significant $(25-43 \%)$ decreases in the mRNA levels of acetyl-CoA carboxylase, fatty acid synthase, ATP-citrate lyase and L-pyruvate kinase. The diets containing 2.5 and $5 \mathrm{~g}$ lipoic acid/ $\mathrm{kg}$ further decreased these parameters, and the values obtained with a diet containing $5 \mathrm{~g}$ lipoic acid $/ \mathrm{kg}$ were less than one-half those observed with a lipoic acidfree diet. Consistent with the findings regarding the enzyme activities, lipoic acid-dependent decreases in mRNA levels of glucose 6-phophate dehydrogenase and malic enzyme were attenuated. Decreases were only $12-17 \%$ with diets containing 1 and $2.5 \mathrm{~g}$ lipoic acid/ $\mathrm{kg}$, and were 25 and $34 \%$ lower in rats fed a diet containing $5 \mathrm{~g}$ lipoic acid/ $\mathrm{kg}$ than in those fed a diet free of this compound.

Spot 14 and adiponutrin are proteins presumed to be involved in the regulation of lipogenesis ${ }^{(33-35)}$. Dietary lipoic acid at a dietary level as low as $1 \mathrm{~g} / \mathrm{kg}$ greatly decreased mRNA levels of these proteins (40 and 35\% decreases for spot 14 and adiponutrin, respectively). Diets containing 2.5 and $5 \mathrm{~g}$ lipoic acid/kg further decreased these parameters. It has been well demonstrated that SREBP-1 is a transcription factor involved in the regulation of the gene expression of many lipogenic enzymes ${ }^{(13)}$. In addition, this transcription factor up regulates the gene expression of enzymes involved in the desaturation of SFA (stearoyl-CoA desaturase 1) ${ }^{(36)}$ and PUFA $\left(\Delta^{5} \text { - and } \Delta^{6} \text {-desaturases }\right)^{(37)}$. We therefore measured the mRNA expression of these desaturases. Dietary lipoic acid also dose-dependently decreased mRNA levels of these desaturases. This compound at a dietary level of $1 \mathrm{~g} / \mathrm{kg}$ caused $26-38 \%$ decreases in these parameters. The values in rats given a diet containing $2.5 \mathrm{~g}$ lipoic acid/kg were approximately one-half those in the animals given a diet free of this compound. A diet containing $5 \mathrm{~g}$ lipoic acid $/ \mathrm{kg}$ further decreased these parameters, and the reduction was 


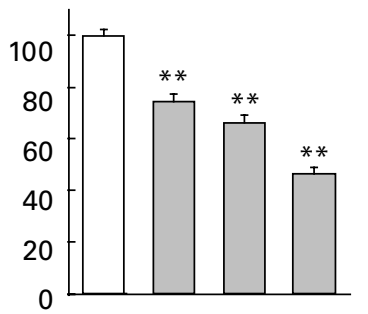

Glucose 6-phosphate dehydrogenase
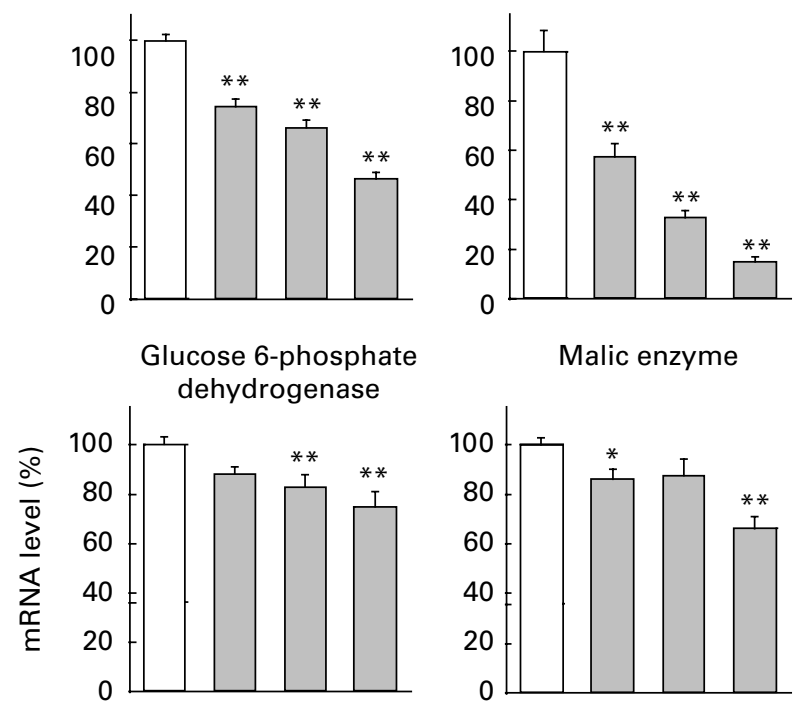

Adiponutrin

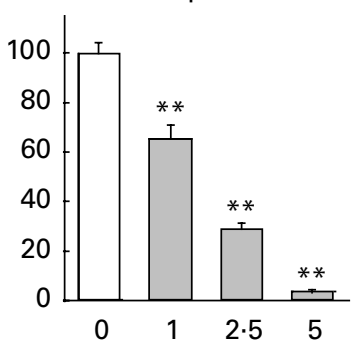

$\Delta^{5}$-desaturase

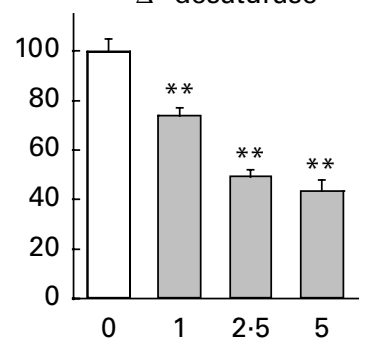

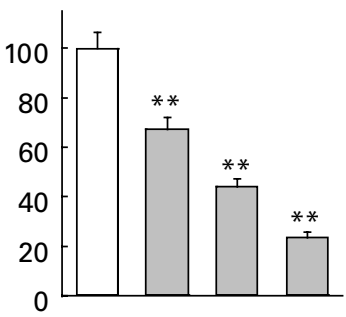

L-Pyruvate kinase

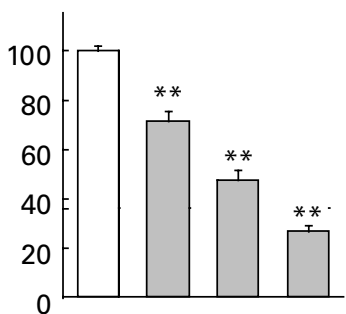

$\Delta^{6}$-desaturase

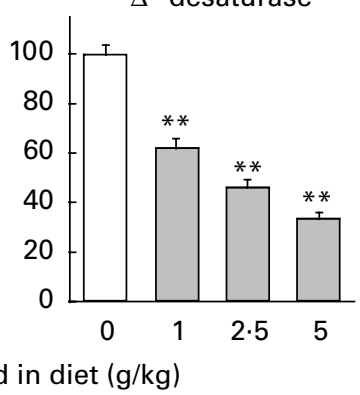

Spot 14

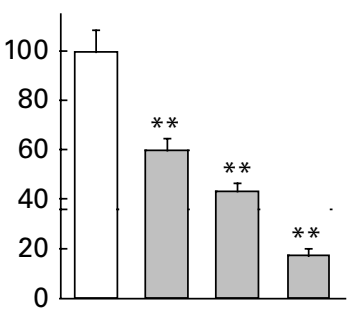

Lipoic acid in diet $(\mathrm{g} / \mathrm{kg})$

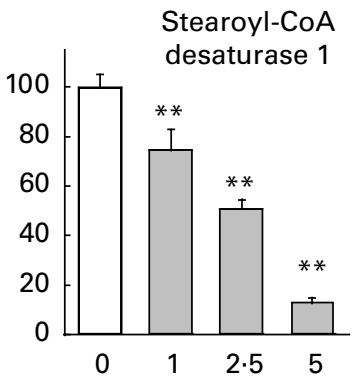

Fig. 2. Effect of dietary lipoic acid on mRNA levels of hepatic proteins involved in lipogenesis and fatty acid desaturation. Values are means with their standard errors depicted by vertical bars $(n 7-8)$. Mean values were significantly different from those of rats fed a lipoic acid-free diet: ${ }^{\star} P<0 \cdot 05,{ }^{\star \star} P<0 \cdot 01$.

most prominent with stearoyl-CoA desaturase 1. The observations in the present study therefore indicated that lipoic acid decreased hepatic lipogenesis through a SREBP-1-dependent mechanism. However, lipoic acid did not significantly modify mRNA levels of two isoforms of this transcription factor. mRNA levels of SREBP-1a in rats fed diets containing $0,1,2.5$ and $5 \cdot 0 \mathrm{~g} / \mathrm{kg}$ were 100 (SEM 6), $92 \cdot 5$ (SEM 3.7), 113 (SEM 4) and $108 \%$ (SEM 6), respectively. Those of SREBP1c were 100 (SEM 15), 83.7 (SEM 6.3), 98.2 (SEM 7.4) and $87.7 \%$ (SEM 9.5), respectively.

Lipoic acid was rather ineffective in modulating serum cholesterol levels. However, this compound decreased not only the concentration of TAG, but also that of cholesterol in the liver. We therefore measured mRNA levels of enzymes involved in the cholesterogenic pathway. Although a diet containing $1 \mathrm{~g}$ lipoic acid/ $\mathrm{kg}$ compared to a diet free of this compound did not affect the mRNA level of cytoplasmic 3-hydroxy-3-methylglutaryl-CoA synthase (100 (SEM 6) and 94.7 (SEM 5.6) \% for rats given diets containing 0 and $1 \mathrm{~g}$ lipoic acid/ $\mathrm{kg}$, respectively), diets containing 2.5 and $5 \mathrm{~g}$ lipoic $\mathrm{acid} / \mathrm{kg}$ significantly decreased this parameter (73.2 (SEM 3.8 ) and 62.8 (SEM 5.2) \%, respectively). Diets containing 1 and $2.5 \mathrm{~g}$ lipoic acid/ $\mathrm{kg}$, however, did not affect mRNA levels of 3-hydroxy-3-methylglutaryl-CoA reductase and farnesyl diphosphate synthase, and a diet containing $5 \mathrm{~g}$ lipoic acid/kg slightly but significantly increased these values (120 (SEM 7) and 121 (SEM 9) \% for 3-hydroxy-3methylglutaryl-CoA reductase and farnesyl diphosphate synthase, respectively). SREBP-2 is a transcription factor involved in the regulation of the gene expression of these cholesterogenic enzymes and the LDL receptor ${ }^{(13)}$. A diet containing $5 \mathrm{~g}$, but not 1 or $2.5 \mathrm{~g}$ lipoic acid $/ \mathrm{kg}$, relative to a lipoic acid-free diet significantly decreased mRNA levels of the LDL receptor (100 (SEM 4) and 71.2 (SEM 2.5) \% in rats fed diets containing 0 and $5 \mathrm{~g}$ lipoic acid/ $\mathrm{kg}$, respectively). Dietary lipoic acid did not affect mRNA levels of SREBP-2 (data not shown). Therefore, the impact of lipoic acid on the mRNA expression of cholesterogenic enzymes was rather moderate and inconsistent.

Dietary lipoic acid considerably modified serum concentrations of adipokines (adiponectin and leptin). However, lipoic acid at various dietary levels was totally ineffective in modifying mRNA levels of these adipokines in epididymal white adipose tissue (data not shown). We also measured mRNA levels of various proteins (glucose transporter 4, adiponutrin, PPAR $\gamma 2$, lipoprotein lipase, adipocyte lipid-binding protein and fatty acid translocase/CD36) in epididymal fat depot. However, lipoic acid was rather ineffective in altering these mRNA levels and only slight changes (16-20\%) were observed on some occasions. 


\section{Discussion}

In the present study, we confirmed previous findings that dietary lipoic acid reduces serum and tissue lipid levels ${ }^{(4,8-11)}$ despite that this compound was rather ineffective in reducing serum cholesterol levels, and increased the hepatic concentration of phospholipid. Moreover, we showed that this compound dose-dependently reduced hepatic activity and mRNA levels of lipogenic enzymes, and circulating insulin and leptin levels, but increased the serum adiponectin concentration. As the diet containing $5 \mathrm{~g}$ but not 1 or $2.5 \mathrm{~g}$ lipoic $\mathrm{acid} / \mathrm{kg}$ considerably decreased the food intake of animals, the largest effect seen with the highest dose may be related to side-effects or toxic effects of the compound. Generally, diets containing high levels of lipoic acid reduce the intake of food in rats ${ }^{(10-12,15)}$. It is currently unknown if this represents toxicity or a problem with the palatability of the compound. A study suggested that lipoic acid decreased the activity of AMP-activated protein kinase (AMPK) in the hypothalamus and hence reduced food intake ${ }^{(15)}$. Significant clinical toxicity of lipoic acid assessed by changes in serum ammonia and amino acid concentrations has been observed in cats ${ }^{(38)}$. However, no sign of the toxicity of lipoic acid in rats was observed in a 2-year study even at a high dose that reduces food intake ${ }^{(39)}$. Therefore, it is unlikely that the large effects seen with a diet containing $5 \mathrm{~g}$ lipoic acid $/ \mathrm{kg}$ are related to the toxicity of lipoic acid. However, it is possible that the large reductions in hepatic lipogenesis, serum and liver lipid levels, and circulating levels of insulin and leptin seen with a diet containing $5 \mathrm{~g}$ lipoic acid $/ \mathrm{kg}$ represent not only the physiological activity of lipoic acid but also a consequence of the reduction of food intake, because it is well demonstrated that food deprivation causes profound decreases in these parameters ${ }^{(40,41)}$.

Dietary lipoic acid reduced hepatic concentrations of TAG and cholesterol, but increased the value for phospholipid. This may imply the proliferation of hepatic organelles like the endoplasmic reticulum, lysosomes, mitochondria and peroxisomes. In fact, increases in hepatic phospholipid levels are reported in rats treated with drugs and food components that increase the activity and expression of hepatic lysosomal acid phosphatase $^{(42)}$, microsomal drug-metabolizing enzymes ${ }^{(43)}$, and mitochondrial and peroxisomal fatty acid oxidation enzymes ${ }^{(44)}$. As we did not observe lipoic acid-dependent increases in the activities of mitochondrial carnitine palmitoyltransferase and peroxisomal palmitoyl-CoA oxidase in the present study (data not shown), an increase in the hepatic phospholipid concentration may not represent the proliferation of mitochondria and peroxisomes.

We observed that lipoic acid reduced the activity and mRNA levels of enzymes involved in hepatic fatty acid synthesis and pyruvate kinase, and mRNA levels of proteins presumed to be involved in the regulation of lipogenesis (spot 14 and adiponutrin) ${ }^{(33-35)}$. Therefore, it is highly possible that reduced hepatic lipogenesis is a principal mechanism for the lipid-lowering effect of this compound. However, the lipoic acid-dependent decreases in the activity and mRNA expression of NADPH-producing enzymes (glucose 6-phosphate dehydrogenase and malic enzyme) were rather moderate. It has been suggested that NADPH-producing enzymes not only play a role in the regulation of lipogenesis, but also are involved in the attenuation of oxidative stress in tissues ${ }^{(45)}$. Therefore, the responses different from those of other lipogenic enzymes may in some way be related to the anti-oxidative activity of lipoic acid ${ }^{(3-6)}$. Lipoic acid reduced mRNA levels not only of enzymes and proteins involved in lipogenesis, but also of stearoyl-CoA desaturase 1, and $\Delta^{5}$ - and $\Delta^{6}$-desaturases. This observation supports the notion that the SREBP-1 signalling pathway is involved in the regulation of lipogenic enzymes, because this transcription factor up regulates the gene expression not only of many lipogenic enzymes, but also of the enzymes involved in the desaturation of fatty acids ${ }^{(36,37)}$. Although lipoic acid was not effective in reducing mRNA levels of two isoforms of this transcription factor in the present study, it is still possible that this compound impairs the proteolytic cleavage of the membranebound immature form of this transcription factor to convert it to the mature form located in the nucleus without altering its gene expression and hence affects hepatic lipogenesis. An analysis of the nuclear levels of the mature form of SREBP-1 is required to clarify this point.

In relation to the physiological activity of lipoic acid in reducing hepatic lipogenesis, we observed that lipoic acid dose-dependently reduced serum concentrations of insulin. It is well documented that insulin up regulates hepatic lipogenic enzymes through a SERBP-1-dependent mechanism ${ }^{(13,41)}$. Therefore, the lipoic acid-dependent decrease in the activity and mRNA levels may be caused by the reduction in circulating insulin levels. An insulin-lowering action of lipoic acid in rats has also been reported ${ }^{(4,11,16)}$. In relation to this, Song et al. ${ }^{(11)}$ examined the effect of lipoic acid on pancreatic morphology in obese OLETF rats. They observed that OLETF rats, compared with control Long-Evans Tokushima Otsuka rats, showed a dispersion and reduction in the number of the insulin-positive cells in pancreatic islets. The abnormalities observed with OLETF rats were ameliorated by the treatment with lipoic acid even though this compound significantly reduced the serum concentration of insulin. Therefore, it is unlikely that lipoic acid impairs the function of the pancreas and hence reduces the circulating insulin level. Many studies have indicated that lipoic acid promotes the insulin-mediated transport of glucose or mimics the action of insulin to stimulate the utilization of glucose in muscle ${ }^{(46,47)}$ and 3T3-L1 adipocytes $^{(48,49)}$. Therefore, it is likely that dietary lipoic acid spares insulin that is required to metabolize glucose and hence reduces the pancreatic secretion and serum concentration of this hormone.

We also observed that lipoic acid significantly reduced serum concentrations of leptin, but increased those of adiponectin without altering mRNA levels of these adipokines in epididymal adipose tissue in the present study. Therefore, lipoic acid may affect factors other than the transcription of genes and mRNA stability and hence modulate serum concentrations of these adipokines. Song et al. ${ }^{(11)}$ observed that a diet containing $5 \mathrm{~g}$ lipoic acid/ $\mathrm{kg}$ caused about a $65 \%$ decrease in serum leptin concentrations in OLETF rats. This observation is well consistent with the result obtained in the present study. As many studies have demonstrated that insulin stimulates the secretion of leptin from adipocytes ${ }^{(50)}$, alterations by lipoic acid of the serum concentration of this adipokine may represent a consequence of the alteration in insulin status of the animals fed this compound. In fact, a strong 
positive correlation between serum concentrations of insulin and leptin was observed in the present study. Studies have indicated that overexpression of leptin reduces hepatic lipogenesis $^{(51)}$ while a deficiency of this adipokine increases ${ }^{(52)}$. In the present study, lipoic acid reduced both serum leptin concentrations and the activity and mRNA levels of hepatic lipogenic enzymes. Therefore, alterations in the serum leptin concentration cannot account for lipoic aciddependent changes in hepatic lipogenesis.

A hypoglycaemic effect of lipoic acid has been observed by many investigators ${ }^{(7)}$, and was confirmed in the present study. Surprisingly, however, no information regarding the effect of lipoic acid on serum adiponectin concentrations has hitherto been available despite that this adipokine exerts a potent insulin-sensitizing effect and hence lowers blood glucose levels ${ }^{(50,53)}$. The present finding that lipoic acid increased serum adiponectin concentrations indicated that this adipokine may be involved in the hypoglycaemic effect of this compound. With regard to the physiological activity of adiponectin in regulating hepatic lipogenesis, this adipokine increases the amount of the phosphorylated form of AMPK in the liver ${ }^{(50,53)}$. AMPK plays a crucial role in regulating fatty acid and glucose metabolism. Activation through phosphorylation of this enzyme in turn stimulates phosphorylation of acetyl-CoA carboxylase and decreases the enzyme activity. This results not only in a diminished lipogenesis, but also in an enhancement of fatty acid oxidation through a decrease in the hepatic concentration of malonyl-CoA, an inhibitor of carnitine palmitoyltransferase I. Moreover, information suggests that the activation of AMPK results in the downregulation of the expression of fatty acid synthase, spot 14, L-pyruvate kinase and SREBP-1 ${ }^{(54,55)}$. Recent studies have indicated that dietary lipoic acid activates AMPK in the aortic endothelium $^{(56)}$, and skeletal muscle ${ }^{(17)}$, but decreases the enzyme activity in the hypothalamus ${ }^{(15)}$. There is the possibility that lipoic acid also affects the activity of AMPK in the liver through an adiponectin-mediated mechanism and hence decreases the gene expression of lipogenic enzymes. In this context, Lee et al. ${ }^{(12)}$ observed an increase in the hepatic content of the active phosphorylated form of AMPK after $4 \mathrm{~d}$ on a diet containing $10 \mathrm{~g}$ lipoic acid/ $\mathrm{kg}$, but not after $42 \mathrm{~d}$ of feeding in acyl-CoA synthase transgenic mice. Therefore, the role of the AMPK-signalling pathway and of adiponectin in lipoic acid-dependent changes in the gene expression of hepatic lipogenic enzymes is not clear at present. There is the possibility that the metabolic responses to lipoic acid observed in acyl-CoA synthase transgenic mice are considerably different from those in Sprague-Dawley rats employed as experimental animals in the present study. Therefore, an analysis of hepatic AMPK activity is required to clarify the role of the AMPK-cascade in the lipoic acid-dependent changes in the hepatic lipogenesis in rats observed currently.

It has been reported that orally administered lipoic acid in rats is well absorbed from the intestine ${ }^{(57)}$. Pharmacokinetic analyses of the metabolic fate of orally and intravenously administered $\left[7,8-{ }^{14} \mathrm{C}\right]$ lipoic acid indicated that $66 \%$ of orally administered lipoic acid is absorbed from the intestine. An alternative evaluation based on measurements of urinary excretion of ${ }^{14} \mathrm{C}$ gave a higher value for the absorption $(93 \%)$. However, information on tissue or serum levels of lipoic acid in animals treated with this compound is lacking except for a report by Khanna et al. ${ }^{(6)}$ who intragastrically administered lipoic acid to rats at a dose of $150 \mathrm{mg} / \mathrm{kg}$ body weight per $\mathrm{d}$ for 8 weeks. However, the treatment caused a mere $35 \%$ insignificant increase in the hepatic concentration of this compound. The dose employed by Khanna et al. ${ }^{(6)}$ approximates that observed in the present study in rats fed the diet containing $2.5 \mathrm{~g}$ lipoic acid/ $\mathrm{kg}$ (168 (SEM 3) $\mathrm{mg} / \mathrm{kg}$ body weight per d) that exerts strong activity in altering parameters of lipid metabolism. Therefore, there is the possibility that metabolite(s) of lipoic acid ${ }^{(6)}$ rather than lipoic acid per se is responsible for the physiological activity of dietary lipoic acid observed currently.

In conclusion, we demonstrated that dietary lipoic acid strongly decreased hepatic activity and mRNA levels of lipogenic enzymes. This may account for the lipid-lowering effect of lipoic acid reported to date. Alterations in serum concentrations of insulin and (or) adiponectin may trigger this consequence.

\section{Acknowledgements}

This study was supported by a grant from the Ministry of Agriculture, Forestry and Fisheries (MAFF) research project "Development of Evaluation and Management Methods for the Supply of Safe, Reliable and Functional Food and Farm Produce" and the United Nation University-Kirin Fellowship Program awarded to D. T. T. H. There are no conflicts of interest for all sources of funding and the contribution of each author to the manuscript.

\section{References}

1. Wollin SD \& Jones PJ (2003) $\alpha$-Lipoic acid and cardiovascular disease. J Nutr 133, 3327-3330.

2. Reed LJ (1998) From lipoic acid to multi-enzyme complexes. Protein Sci 7, 220-224.

3. Amudha G, Josephine A \& Varalakshmi P (2006) Role of lipoic acid in reducing the oxidative stress induced by cyclosporine $\mathrm{A}$. Clin Chim Acta 372, 134-139.

4. Thirunavukkarasu V \& Anuradha CV (2004) Influence of $\alpha$-lipoic acid on lipid peroxidation and antioxidant defence system in blood of insulin-resistant rats. Diabetes Obes Metab 6, 200-207.

5. Arivazhagan P, Thilakavathy $\mathrm{T}$, Ramanathan K, Kumaran S \& Panneerselvam C (2002) Effect of DL- $\alpha$-lipoic acid on the status of lipid peroxidation and protein oxidation in various brain regions of aged rats. J Nutr Biochem 13, 619-624.

6. Khanna S, Atalay M, Laaksonen DE, Gul M, Roy S \& Sen CK (1999) $\alpha$-Lipoic acid supplementation: tissue glutathione homeostasis at rest and after exercise. J Appl Physiol 86, 1191-1196.

7. Henriksen EJ (2006) Exercise training and the antioxidant $\alpha$-lipoic acid in the treatment of insulin resistance and type 2 diabetes. Free Radic Biol Med 40, 3-12.

8. Yi X \& Maeda N (2006) $\alpha$-Lipoic acid prevents the increase in atherosclerosis induced by diabetes in apolipoprotein E-deficient mice fed high-fat/low-cholesterol diet. Diabetes 55, 2238-2244.

9. Malarkodi KP, Balachandar AV \& Varlakshmi P (2003) The influence of lipoic acid on adriamycin-induced hyperlipidemic nephrotoxicity in rats. Mol Cell Biochem 247, 139-145.

10. Ford I, Cotter MA, Cameron NE \& Greaves M (2001) The effects of treatment with $\alpha$-lipoic acid or evening primrose oil 
on vascular hemostatic and lipid risk factors, blood flow, and peripheral nerve conduction in the streptozotocin-diabetic rat. Metabolism 50, 868-875.

11. Song KH, Lee WJ, Koh JM, et al. (2005) $\alpha$-Lipoic acid prevents diabetes mellitus in diabetes-prone obese rats. Biochem Biophys Res Commun 326, 197-202.

12. Lee Y, Naseem RH, Park BH, Garry DJ, Richardson JA, Schaffer JE \& Unger RH (2006) $\alpha$-Lipoic acid prevents lipotoxic cardiomyopathy in acyl CoA-synthase transgenic mice. Biochem Biophys Res Commun 344, 446-452.

13. Horton JD, Goldstein JL \& Brown MS (2002) SREBPs: activators of the complete program of cholesterol and fatty acid synthesis in the liver. J Clin Invest 109, 1125-1131.

14. Reeves PG, Nielsen FH \& Fahey GC Jr (1993) AIN-93 purified diets for laboratory rodents: final report of the American Institute of Nutrition ad hoc writing committee on the reformulation of the AIN-76A rodent diet. J Nutr 123, 1939-1951.

15. Kim MS, Park JY, Namkoong C, et al. (2004) Anti-obesity effects of $\alpha$-lipoic acid mediated by suppression of hypothalamic AMP-activated protein kinase. Nat Med 10, 727-733.

16. Midaoui AE, Elimadi A, Wu L, Haddad PS \& de Champlain J (2003) Lipoic acid prevents hypertension, hyperglycemia, and the increase in heart mitochondrial superoxide production. Am J Hypertens 16, 173-179.

17. Lee WJ, Song KH, Koh EH, Won JC, Kim HS, Park HS, Kim MS, Kim SW, Lee KU \& Park JY (2005) $\alpha$-Lipoic acid increases insulin sensitivity by activating AMPK in skeletal muscle. Biochem Biophys Res Commun 332, 885-891.

18. Ziegler D, Ametov A \& Barinov A (2006) Oral treatment with $\alpha$-lipoic acid improves symptomatic diabetic polyneuropathy: the SYDNEY 2 trial. Diabetes Care 29, 2365-2370.

19. Yadav V, Marracci G, Lovera J, Woodward W, Bogardus K, Marquardt W, Shinto L, Morris C \& Bourdette D (2005) Lipoic acid in multiple sclerosis: a pilot study. Mult Scler 11, $159-165$

20. Kelley DS, Nelson GJ \& Hunt JE (1986) Effect of prior nutritional status on the activity of lipogenic enzymes in primary monolayer cultures of rat hepatocytes. Biochem $J \mathbf{2 3 5}$, 87-90.

21. Takeda Y, Suzuki F \& Inoue H (1969) ATP citrate lyase (citrate-cleavage enzyme). Methods Enzymol 13, 153-160.

22. Hsu RY \& Lardy HA (1967) Pigeon liver malic enzyme. II. Isolation, crystallization, and some properties. J Biol Chem 242, 520-526.

23. Kelley DS \& Kletzien RF (1984) Ethanol modulation of the hormonal and nutritional regulation of glucose 6-phosphate dehydrogenase activity in primary cultures of rat hepatocytes. Biochem J 217, 543-549.

24. Tanaka T, Harano Y, Sue F \& Morimura H (1967) Crystallization, characterization and metabolic regulation of two types of pyruvate kinase isolated from rat tissues. J Biochem 62, 71-91.

25. Chomczynski P \& Sacchi N (1987) Single-step method of RNA isolation by acid guanidium thiocyanate-phenol-chloroform extraction. Anal Biochem 162, 156-159.

26. Lim JS, Adachi Y, Takahashi Y \& Ide T (2007) Comparative analysis of sesame lignans (sesamin and sesamolin) in affecting hepatic fatty acid metabolism in rats. Br J Nutr 97, 85-95.

27. Folch J, Lees M \& Sloane-Stanley GH (1957) A simple method for the isolation and purification of total lipids from animal tissues. J Biol Chem 226, 497-509.

28. Fletcher MJ (1968) A colorimetric method for estimating serum triglycerides. Clin Chim Acta 22, 393-397.

29. Rouser G, Fkeischer S \& Yamamoto A (1970) Two dimensional thin layer chromatographic separation of polar lipids and determination of phospholipids by phosphorus analysis of spots. Lipids 5, 494-496.
30. Ide T, Oku H \& Sugano M (1982) Reciprocal responses to clofibrate in ketogenesis and triglyceride and cholesterol secretion in isolated rat liver. Metabolism 31, 1065-1072.

31. Noguchi T, Inoue H \& Tanaka T (1982) Regulation of rat liver L-type pyruvate kinase mRNA by insulin and by fructose. Eur $J$ Biochem 128, 583-588.

32. Inoue H, Noguchi $\mathrm{T} \&$ Tanaka $\mathrm{T}$ (1986) Complete amino acid sequence of rat L-type pyruvate kinase deduced from the cDNA sequences. Eur J Biochem 154, 465-469.

33. Ide $\mathrm{T}$ (2005) Interaction of fish oil and conjugated linoleic acid in affecting hepatic activity of lipogenic enzymes and gene expression in liver and adipose tissue. Diabetes 54, 412-423.

34. Kinlaw WB, Church JL, Harmon J \& Mariash CN (1995) Direct evidence for a role of the 'spot 14' protein in the regulation of lipid synthesis. J Biol Chem 270, 16615-16618.

35. Jenkins CM, Mancuso DJ, Yan W, Sims HF, Gibson B \& Gross RW (2004) Identification, cloning, expression, and purification of three novel human calcium-independent phospholipase $\mathrm{A}_{2}$ family members possessing triacylglycerol lipase and acylglycerol transacylase activities. J Biol Chem 279, 48968-48975.

36. Ntambi JM (1999) Regulation of stearoyl-CoA desaturase by polyunsaturated fatty acids and cholesterol. J Lipid Res 40, 1549-1558.

37. Matsuzaka T, Shimano H, Yahagi N et al., (2002) Dual regulation of mouse $\Delta^{5}$ - and $\Delta^{6}$-desaturase gene expression by SREBP-1 and PPAR $\alpha$. J Lipid Res 43, 107-114.

38. Hill AS, Werner JA, Rogers QR, O’Neill SL \& Christopher MM (2004) Lipoic acid is 10 times more toxic in cats than reported in humans, dogs or rats. J Anim Physiol Anim Nutr (Berl) 88, $150-156$.

39. Cremer DR, Rabeler R, Roberts A \& Lynch B (2006) Longterm safety of $\alpha$-lipoic acid (ALA) consumption: a 2-year study. Regul Toxicol Pharmacol 46, 193-201.

40. Margetic S, Gazzola C, Pegg GG \& Hill RA (2002) Leptin: a review of its peripheral actions and interactions. Int $J$ Obes Relat Metab Disord 26, 1407-1433.

41. Desvergne B, Michalik L \& Wahli W (2006) Transcriptional regulation of metabolism. Physiol Rev 86, 465-514.

42. Matsuzawa Y \& Hostetler KY (1980) Studies on drug-induced lipidosis: subcellular localization of phospholipid and cholesterol in the liver of rats treated with chloroquine or $4,4^{\prime}$-bis (diethylaminoethoxy) $\alpha, \beta$-diethyldiphenylethane. $J$ Lipid Res 21, 202-214.

43. Orrenius S, Ericsson JL \& Ernster L (1965) Phenobarbitalinduced synthesis of the microsomal drug-metabolizing enzyme system and its relationship to the proliferation of endoplasmic membranes. A morphological and biochemical study. $J$ Cell Biol 25, 627-639.

44. Ashakumary L, Rouyer I, Takahashi Y, Ide T, Fukuda N, Aoyama T, Hashimoto T, Mizugaki M \& Sugano M (1999) Sesamin, a sesame lignan, is a potent inducer of hepatic fatty acid oxidation in the rat. Metabolism 48, 1303-1313.

45. Taniguchi M, Yasutake A, Takedomi K \& Inoue K (1999) Effects of $N$-nitrosodimethylamine (NDMA) on the oxidative status of rat liver. Arch Toxicol 73, 141-146.

46. Saengsirisuwan V, Perez FR, Sloniger JA, Maier T \& Henriksen EJ (2004) Interactions of exercise training and $\alpha$-lipoic acid on insulin signaling in skeletal muscle of obese Zucker rats. Am J Physiol Endocrinol Metab 287, E529-E536.

47. Streeper RS, Henriksen EJ, Jacob S, Hokama JY, Fogt DL \& Tritschler HJ (1997) Differential effects of lipoic acid stereoisomers on glucose metabolism in insulin-resistant skeletal muscle. Am J Physiol 273, E185-E191.

48. Moini H, Tirosh O, Park YC, Cho KJ \& Packer L (2002) R- $\alpha$ lipoic acid action on cell redox status, the insulin receptor, and glucose uptake in 3T3-L1 adipocytes. Arch Biochem Biophys 397, 384-391. 
49. Estrada DE, Ewart HS, Tsakiridis T, Volchuk A, Ramlal T, Tritschler H \& Klip A (1996) Stimulation of glucose uptake by the natural coenzyme $\alpha$-lipoic acid/thioctic acid: participation of elements of the insulin signaling pathway. Diabetes 45, 1798-1804.

50. Huerta MG (2006) Adiponectin and leptin: potential tools in the differential diagnosis of pediatric diabetes? Rev Endocr Metab Disord 7, 187-196.

51. Kakuma T, Lee Y, Higa M, Wang Z, Pan W, Shimomura I \& Unger RH (2000) Leptin, troglitazone, and the expression of sterol regulatory element binding proteins in liver and pancreatic islets. Proc Natl Acad Sci U S A 97, 8536-8541.

52. Iizuka K, Miller B \& Uyeda K (2006) Deficiency of carbohydrate-activated transcription factor ChREBP prevents obesity and improves plasma glucose control in leptin-deficient $(\mathrm{ob} / \mathrm{ob})$ mice. Am J Physiol Endocrinol Metab 291, E358-E364.
53. Kadowaki T \& Yamauchi T (2005) Adiponectin and adiponectin receptors. Endocr Rev 26, 439-451.

54. Leclerc I, Kahn A \& Doiron B (1998) The 5'-AMP-activated protein kinase inhibits the transcriptional stimulation by glucose in liver cells, acting through the glucose response complex. FEBS Lett 431, 180-184.

55. Zhou G, Myers R, Li Y, et al. (2001) Role of AMP-activated protein kinase in mechanism of metformin action. J Clin Invest 108, 1167-1174.

56. Lee WJ, Lee IK, Kim HS, et al. (2005) $\alpha$-Lipoic acid prevents endothelial dysfunction in obese rats via activation of AMPactivated protein kinase. Arterioscler Thromb Vasc Biol 25, 2488-2494.

57. Peter G \& Borbe HO (1995) Absorption of $\left[7,8-{ }^{14} \mathrm{C}\right] \mathrm{rac}-\alpha-$ lipoic acid from in situ ligated segments of the gastrointestinal tract of the rat. Arzneimittelforschung 45, 293-299. 